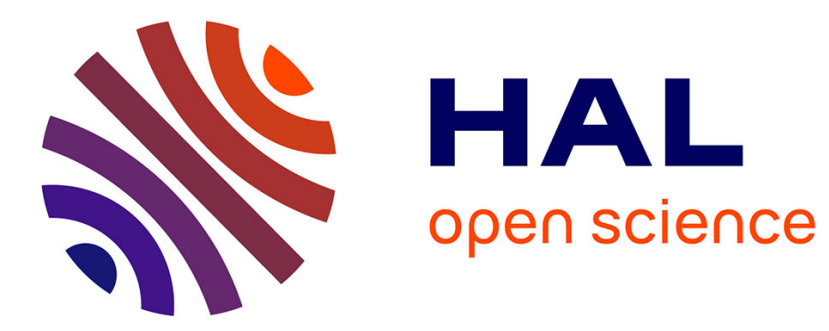

\title{
Treating mine waters in the Lorraine coal field - feedback from the La Houve treatment plant
}

Nicolas Koeberlé, Roger Levicki, Joël Kaiser, Sonia Heitz

\section{To cite this version:}

Nicolas Koeberlé, Roger Levicki, Joël Kaiser, Sonia Heitz. Treating mine waters in the Lorraine coal field - feedback from the La Houve treatment plant. Mine Closure 2013, Sep 2013, Cornwall, United Kingdom. pp.171-182. hal-00849990

\section{HAL Id: hal-00849990 https: / hal-brgm.archives-ouvertes.fr/hal-00849990}

Submitted on 9 Oct 2013

HAL is a multi-disciplinary open access archive for the deposit and dissemination of scientific research documents, whether they are published or not. The documents may come from teaching and research institutions in France or abroad, or from public or private research centers.
L'archive ouverte pluridisciplinaire HAL, est destinée au dépôt et à la diffusion de documents scientifiques de niveau recherche, publiés ou non, émanant des établissements d'enseignement et de recherche français ou étrangers, des laboratoires publics ou privés. 


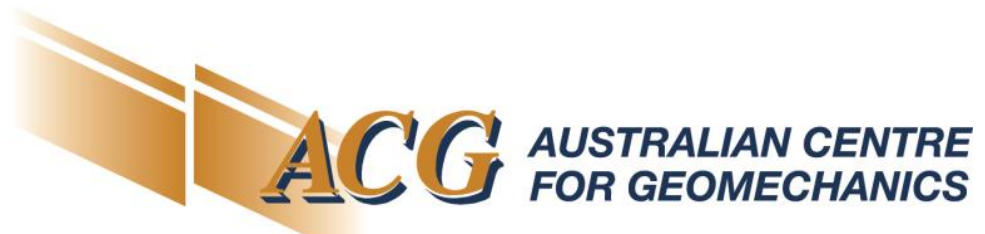

CSIRO | Curtin University I The University of Western Australia

Joint Venture

(C) Copyright 2013, Australian Centre for Geomechanics (ACG), The University of Western Australia. All rights reserved. No part of any ACG publication may be reproduced, stored or transmitted in any form without the prior written permission of the ACG.

The following paper appeared in Mine Closure 2013 proceedings published by the Australian Centre for Geomechanics.

Authors of the paper and third parties must obtain written permission from the ACG to publish all or part of this paper in future works. Suitable acknowledgement to the original source of publication must be included.

Note to authors: This version of your work is owned by the ACG.

This material may be used only on the following conditions:

- Copies of the material may be saved or printed for personal use only and must not be forwarded or sold to any third party.

- Commercial exploitation of the material is prohibited.

For further information:

Publication Sales Officer

Australian Centre for Geomechanics

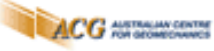

PO Box 3296 - BROADWAY

NEDLANDS WA 6009

AUSTRALIA

Mine Closure 2013

Ph: +61 864883300

sales-acg@uwa.edu.au

www.acg.uwa.edu.au

Proceedings of the Eighth International

Conference on Mine Closure

18-20 September 2013 | Cornwall | England
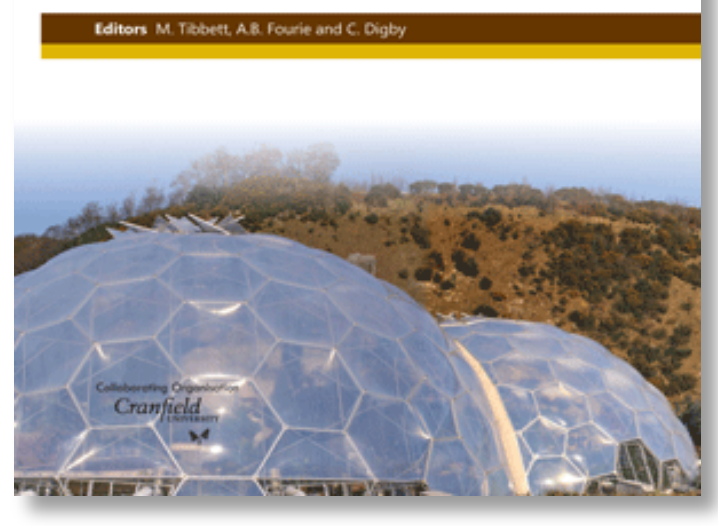


\title{
Treating mine waters in the Lorraine coal field-feedback from the La Houve treatment plant
}

\author{
N. Koeberlé, BRGM/DRP/DPSM, France \\ R. Levicki, BRGM/DRP/DPSM, France \\ J. Kaiser, BRGM/DRP/DPSM, France \\ S. Heitz, BRGM/DRP/DPSM, France
}

\begin{abstract}
Coal extraction in the Lorraine coal field ended in 2004, after 150 years of mining. Stopping of mine drainage pumping caused the flooding of 180 million $\mathrm{m}^{3}$ of mine cavities. After around 2 to 5 years of filling, pumping became necessary to keep pace with rising levels of iron-containing water.

The elevated levels of iron mineralisation in the mine water are such that the water cannot be discharged directly into the natural environment, making treatment a necessity. In the Lorraine coal field, the complete treatment system will comprise three treatment plants with a maximum cumulative flow rate estimated at $1,000 \mathrm{~m}^{3} / \mathrm{h}$. The plants are of the passive type with the mine water flowing over aeration cascades into settling tanks and lagoons planted with reeds, before being discharged into the natural environment. Two plants are currently operating, one since 2009 the other since 2012. The La Houve plant, in operation since 2009, has provided experience over three years and this feedback enables a comparison with initial predictions.

The first results show that the model for decrease in the iron concentration of the mine water used initially does not fit with the La Houve case. We have formulated a hypothesis allowing adjustment of the model to observations; other phenomena remain to be studied to explain the behaviour of the mine reservoir. Where treatment plant efficiency is concerned, 98 per cent of iron is removed on average and there is a seasonal pattern.
\end{abstract}

\section{$1 \quad$ Introduction}

When a mine operator can no longer be traced, a number of legislative provisions entrust the French state with the responsibility for the facilities and equipment needed for management of the post-closure phase. In France, the Bureau des recherches géologiques et minières (BRGM - French National Geological Survey) has been tasked with operational management of post-closure since 2008.

\subsection{Geographical situation and brief historical background}

The Lorraine coal field, in the north-east of France, covers an area of around $500 \mathrm{~km}^{2}$ (Figure 1). Some 140 coal beds have been worked over the entire field, with thicknesses from a few tens of centimetres to more than four metres. In 150 years of mining (1856-2004), around 800 million tonnes of coal were extracted and 58 mine shafts were sunk to depths up to $1,250 \mathrm{~m}$. The volume of the residual cavities is estimated at 180 million $\mathrm{m}^{3}\left(\mathrm{Mm}^{3}\right)$. 


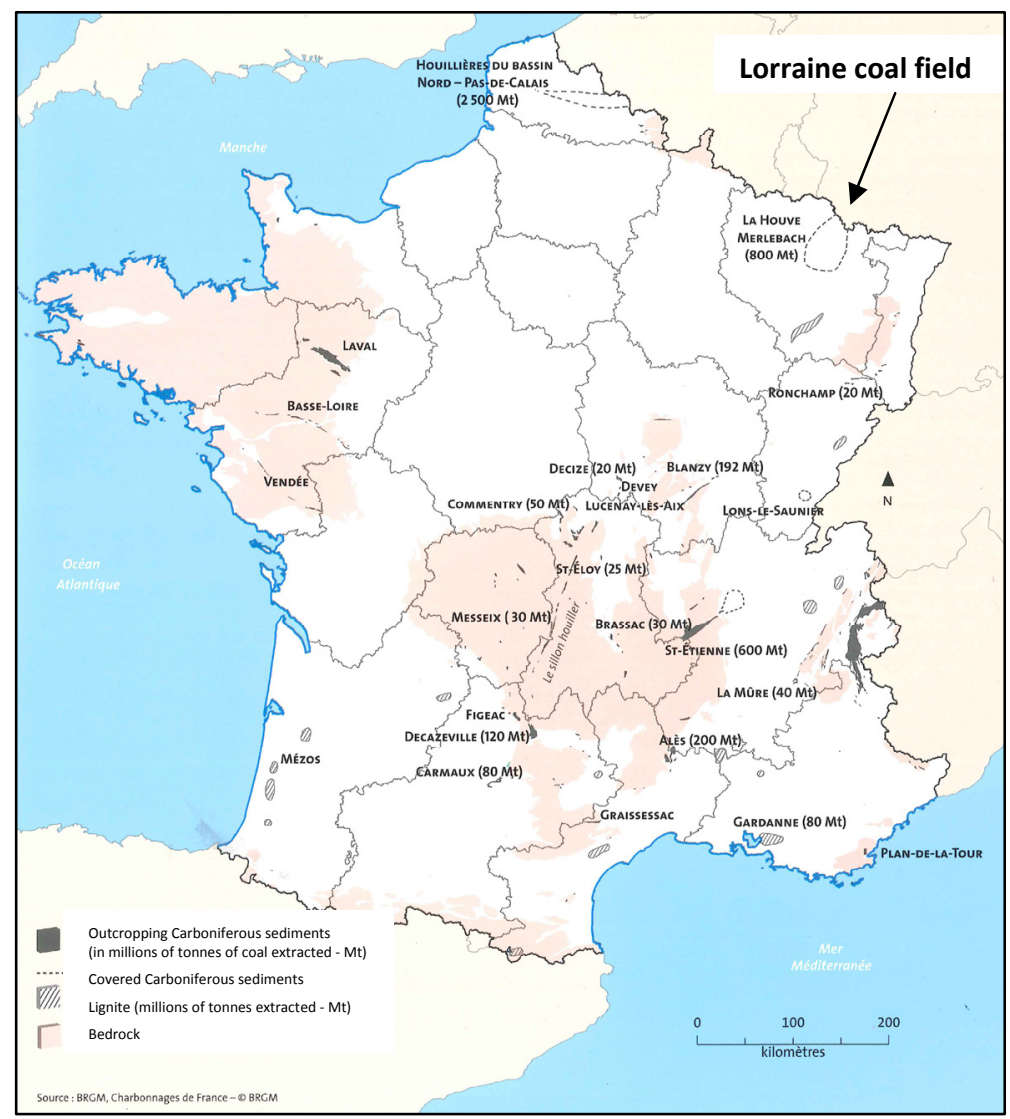

Figure 1 Overall geographical situation (source : BRGM, Charbonnage de France)

\subsection{Geological context}

Mines in the Lorraine region worked coal at depths of between 150 and 1,250 m. The coal seams lie between sandstone, schist and conglomerate formations that together form the coal measures. The groundmass of the coal measures is very fine and they are considered to be only very slightly permeable when they have not been worked (permeability around $10^{-7}$ to $10^{-9} \mathrm{~m} / \mathrm{s}$ ).

There is an unconformity between the overlying Permian formation and the coal measures, made up of conglomerates with, at some points, a more clayey level at the base. Like the coal measures - except where they are fractured as a result of mining - the Permian formation is considered to be impermeable.

Lastly, the permocarboniferous is overlain by Triassic formations consisting, for the most part, of Lower Triassic sandstone (LTs) outcropping in the coal field. The groundwater in the LTs constitutes the region's water resource, used both by industry and for drinking water.

\subsection{Hydrogeological circulation and filling of mine cavities}

Use of caving techniques has caused fracturing and subsidence of the overlying terrain (as much as $15 \mathrm{~m}$ of subsidence in some places). In particular, fractures in the Permian formations and in the coal measures have made these formations permeable and large quantities of groundwater from the Lower Triassic Sandstone (LTS) have flowed into the mines, notably via the most severely fractured areas directly above the workings. As a result vast drawdown cones have formed in the LTs layers.

During mining operations, mine dewatering flow rates reached around $4,000 \mathrm{~m}^{3} / \mathrm{h}$ over the coal field. The short retention time of the water in the mine meant that it was not mineralised (Blachere, 2003) ${ }^{a}$. The drained water flowed through settling basins and was sold for industrial use, with the surplus being discharged directly into the natural environment. 
From the hydrogeological point of view, the mine workings form two separate reservoirs : the western reservoir and the central-eastern reservoir (Figure 2). Stopping of pumping caused the mines to flood and the mine reservoirs to fill.

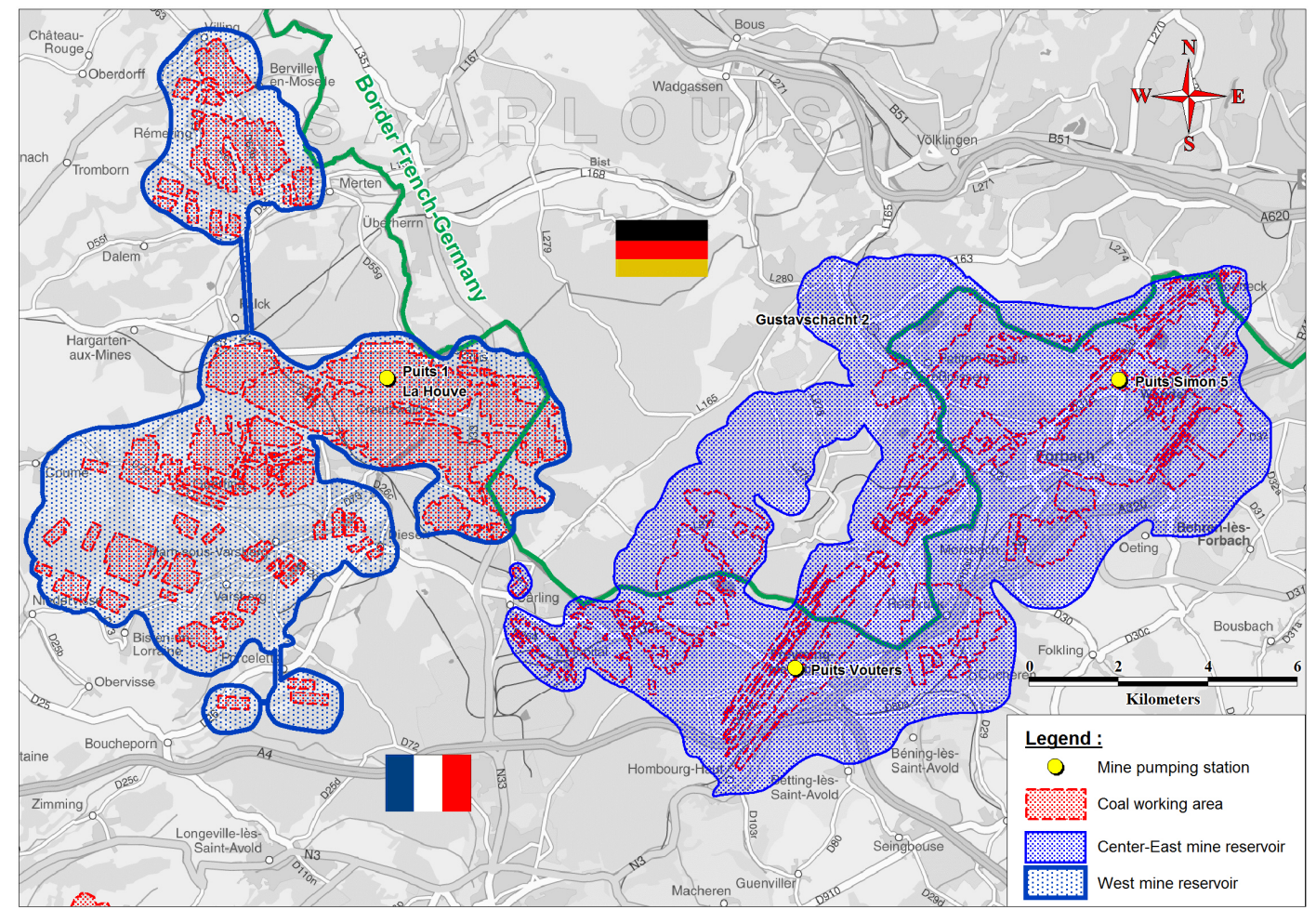

Figure 2 Mine workings footprint and mine reservoir perimeters

\section{The pumping and water treatment system}

\subsection{Purposes of pumping}

Over the 150 years of mine operation, circulation of oxygen through the mines caused partial oxidation of the sulphur-containing minerals present in the coal measures, especially of pyrite $\left(\mathrm{FeS}_{2}\right)$. The products of this oxidation are deposited on the walls and in all of the fractures in the worked zone. When the mines are flooded these oxides go into solution.

In the Lorraine coal field, there is a risk that the rising highly mineralised mine water could contaminate the LTs aquifer via its base. The risk of mineralised plumes is greater at the drawdown cones formed by infiltration into the mine (ANTEA, 2004).

To avoid contamination of the LTs aquifer, the mine water is to be pumped out of the reservoir to keep pace with the rise in water level. The aim is to keep the mine reservoir level below the low point of the LTs groundwater. In this way, flow will always be from the groundwater to the mine, thereby avoiding rise of the mine water into the LTs groundwater. 


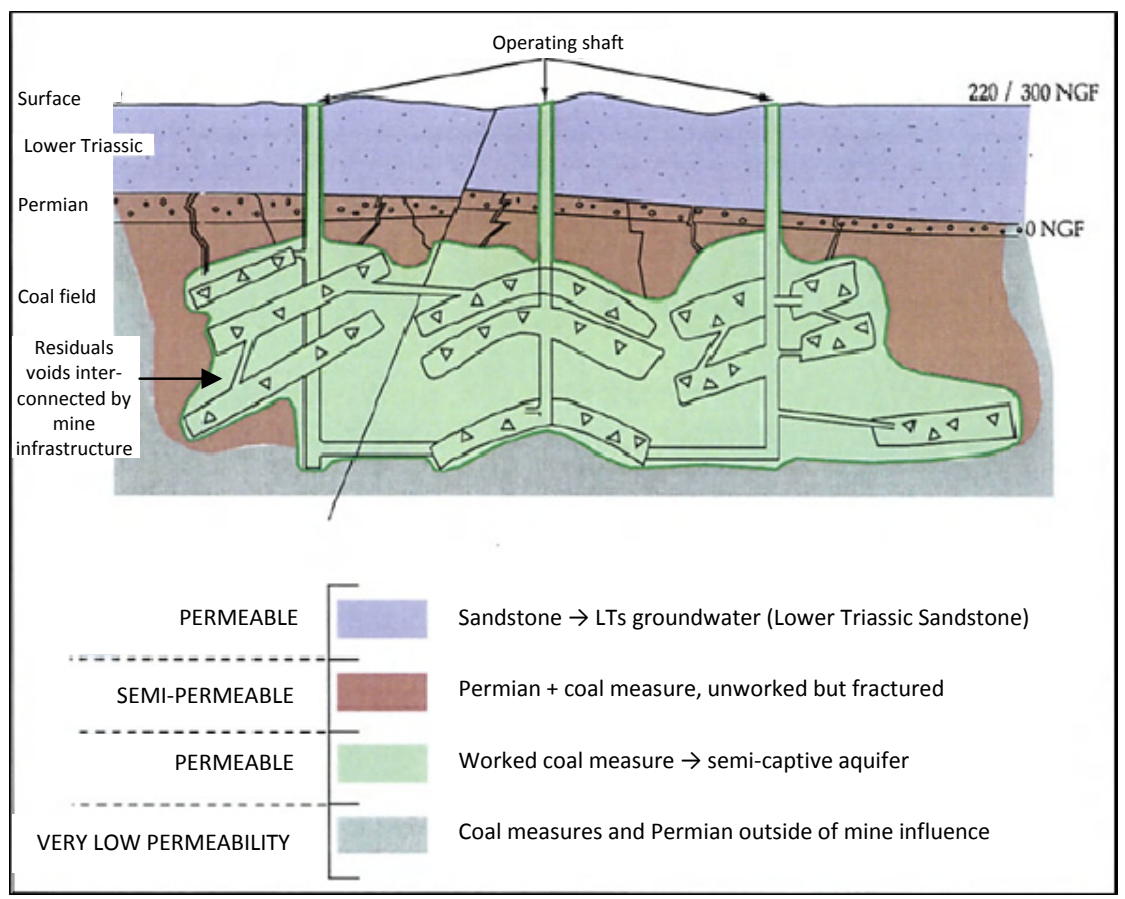

Figure 3 The general hydrogeological context of the Lorraine coal field (Source: CESAME)

The second objective of pumping is protection of the built environment. In certain areas of subsidence the highest level of the LTs water table is at less than three metres from the surface or may even be above the current surface level, which could be damaging to houses built during the mining operations. Pumping will also make it possible to maintain the final level of the LTs groundwater at more than three metres below the surface, thereby preserving the built areas. In the areas of greatest vulnerability, this scheme will be completed by 15 boreholes to lower the water level.

\subsection{The solution adopted}

The full system for control of rising water levels in the mine reservoirs comprises three pumping stations and water treatment plants (the locations of the units are shown in Figure 2) :

- one unit in the western reservoir, commissioned at the end of 2009 (La Houve);

- two units in the centre and eastern reservoir, of which the Simon 5 unit was commissioned at the end of 2012.

The two units operating currently in the Lorraine coal field are of the passive type. The design applied is as defined in the PIRAMID European research and development project: "passive treatment is the improvement of water quality using only naturally-available energy sources, in gravity-flow treatment systems (such as wetlands or subsurface-flow bioreactors) which are designed to require only infrequent (albeit regular) maintenance to operate successfully over their design lives." (PIRAMID, 2003). The principle and geometric characteristics of their operation is shown in Figure 4 and Table 1.

The volume of the ponds is calculated to ensure a retention time that is sufficient for adequate settling of the iron hydroxides.

The kinetics of precipitation are such that it takes precedence over that of manganese. It is only once the iron is precipitated that the manganese can oxidise and then precipitate. This will be provided for in shallow lagoons planted with macrophytes. 
1 - Aeration of the water by cascading converts the soluble iron into reddish, insoluble iron hydroxide. Settling takes place progressively

3 - After a treatment run of around two days, the water is checked then discharged into the natural environment

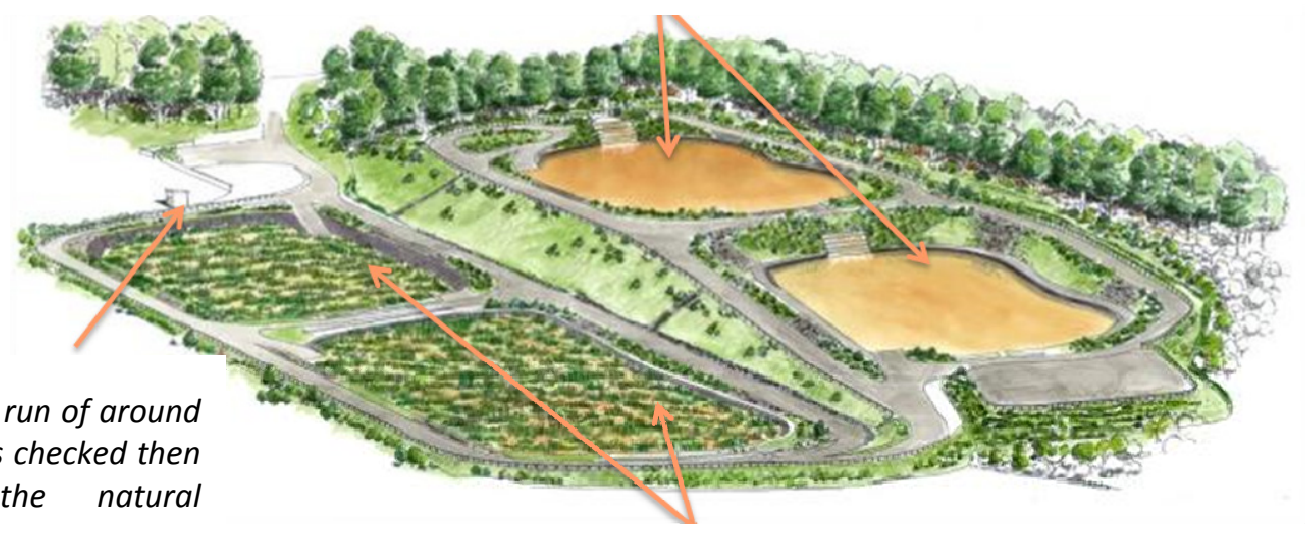

2 - The water then flows into lagoons planted with reeds

Figure 4 Principle of a treatment plant (Simon 5 unit)

Table 1 Geometric characteristics of an operating plant

\begin{tabular}{|c|c|c|c|c|}
\hline Plant & Type of basin & Number & $\begin{array}{c}\text { Area of } \\
\text { water body } \\
\left(\mathrm{m}^{2}\right)\end{array}$ & $\begin{array}{c}\text { Working } \\
\text { volume } \\
\left(\mathrm{m}^{3}\right)\end{array}$ \\
\hline \multirow{2}{*}{ La Houve unit } & Settling ponds & 1 & 1,800 & 5,000 \\
\hline & Lagoons planted with reeds & 3 & 3,400 & - \\
\hline \multirow{2}{*}{ Simon 5 plant } & Settling ponds & 2 & 3,000 & 8,000 \\
\hline & Lagoons planted with reeds & 2 & 3,400 & - \\
\hline
\end{tabular}

\subsection{Predicted iron concentrations with the Younger model (Blachere, 2003)}

When a mine is flooded the oxides formed when the mine was operating go into solution and oxidation of the pyrite stops rapidly due to lack of oxygen. This first phase of filling of the mine therefore mobilises a finite stock of soluble iron. The peak iron concentration in the mine water should be obtained at the end of flooding in 2008. The iron concentration will then decrease following a dilution curve (equation 1). This decrease in iron concentration over time was studied and modelled by P. L. Younger (Newcastle University, UK) (Blachere, 2003) .

The Younger model, derived from observations of more than 80 abandoned mines in Great Britain, provides a useful predictive tool, proposing quantification of three parameters that are characteristic of mine flooding:

- A first mineralisation peak at the end of mine flooding. This maximum concentration (Cpeak) is a function of the total sulphur content of the deposit. 
- Decrease in concentration over time. The time by which the maximum concentration is halved (Cpeak/2) is equal to the filling time of the mine. This is a dilution model.

- The final iron concentration (Cstab) in the resurgence, which is also a function of the total sulphur content of the coal and of the distance of the resurgence from areas of outcropping. Outcrops are considered as potential sources of oxidation of the pyrite.

In 2003, when the mine operator conducted studies of mine flooding in the Lorraine region, the Younger model was compared with other coal extraction operations in France. The maximum and final iron concentrations fitted well with the model. The kinetics of decrease were in line with the observations made for small mines with short filling times. For larger reservoirs, decrease times were much shorter than those predicted and the phenomenon was interpreted as partial mobilisation of the reservoir water. The time by which the maximum concentration was halved corresponded, in this case, to 10 to 15 per cent of the mine filling time.

In the hydrogeological context of La Houve, the hypothesis of partial mobilisation is acceptable, since water enters the mine via the top of the reservoir (LTs/coal measure contact) and pumping from the mine reservoir is in the mine shaft above the coal measures. It is therefore probable that the water flows preferentially via the first levels fractured by operations and that only the upper part of the mine reservoir is leached by pumping.

In the case of the western La Houve reservoir, the values used in the study are shown in Table 2. The decrease curve is shown in Figure 6.

Table 2 Concentrations and characteristic times for the La Houve reservoir

\begin{tabular}{ccc}
\hline & Concentration $\mathrm{mg} / \mathrm{L}$ & Time \\
\hline C peak & $98( \pm 25 \%)$ & 0 \\
C p peak $/ 2$ & $49( \pm 25 \%)$ & 8 to 20 months \\
C stab & 3 to 5 & 6 years
\end{tabular}

\section{Feedback from the La Houve plant}

\subsection{Kinetics of filling of the mine reservoir}

In the western sector of the Lorraine coal field, pumping of mine water ceased on 11 December 2006. The mine reservoir, with an estimated volume of $18 \mathrm{Mm}^{3}$, filled over two years, in three phases (Figure 5):

- A first rapid rise phase, observed between levels -580 m NGF (French elevation datum) and -250 m NGF. This corresponds to flooding of the mine by declines from the bottom of the shaft. The residual void space of these levels is relatively small in comparison with the reservoir volume.

- A second phase of rise, between $-250 \mathrm{~m}$ NGF and $+50 \mathrm{~m}$ NGF, corresponding to filling of the residual voids left by the largest mining operations.

- A third, more rapid, filling phase in the fourth quarter of 2008. On the assumption that there is no increase in the rate of inflow into the mine during this period, this acceleration is interpreted as filling of the fractures in the coal measures above the highest mining operations.

The end of filling of the coal measures is accompanied by a sharp drop in the rate of water rise. The slower rise in potentiometric level after filling of the mine reservoir corresponds to the head resulting from rise in level of the LTs groundwater. 


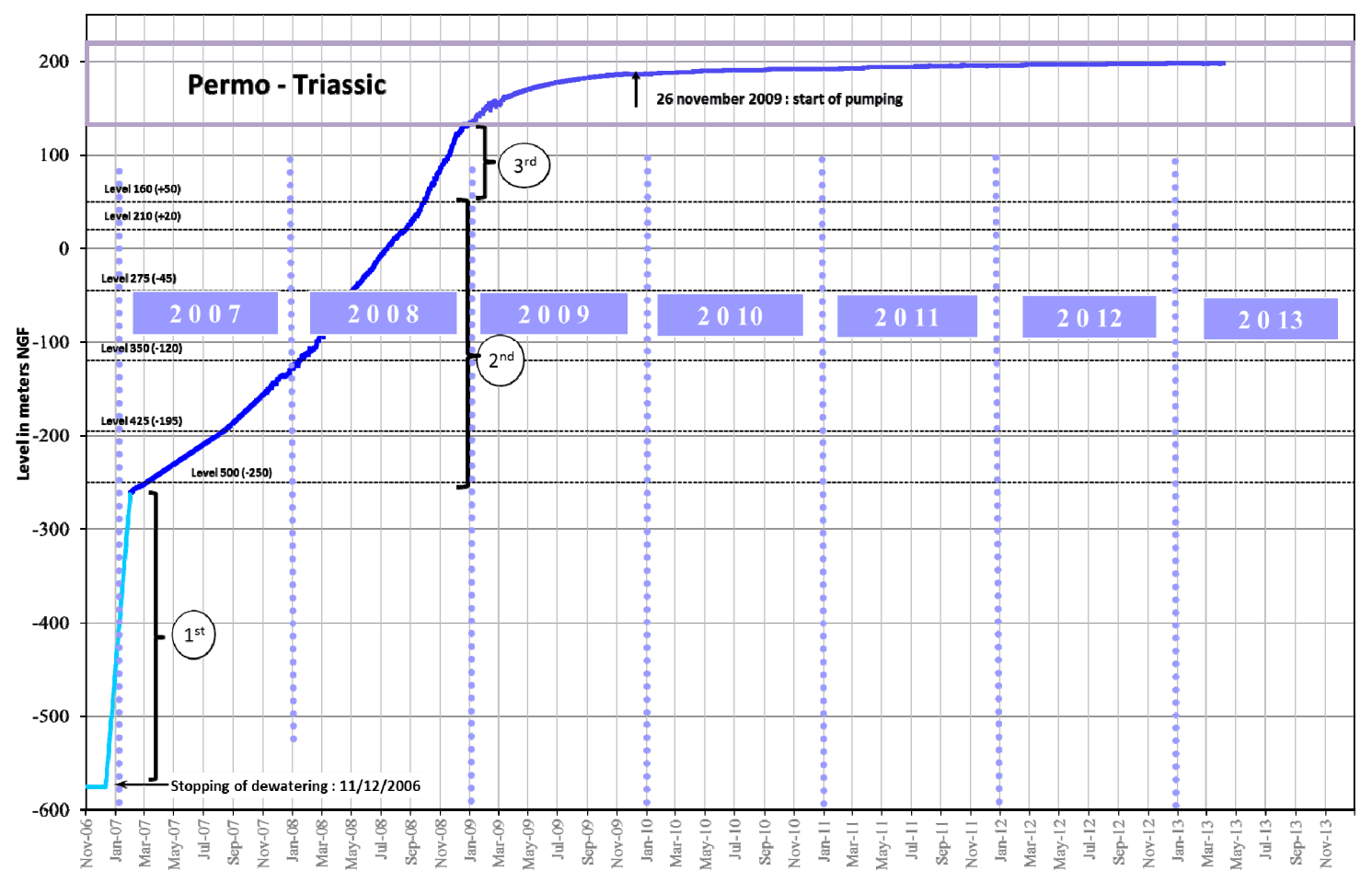

Figure 5 Water level in mine reservoir, western sector

\subsection{Evolution in iron concentrations}

The concentrations observed since November 2009 in the La Houve reservoir do not correspond to the study forecasts, the overall trend emerging being one of slight increase (Figure 6). Taking a more detailed view, the measured concentrations show a rise during the first two years of pumping (from 20 to $40 \mathrm{mg} / \mathrm{L}$ ). Since the middle of 2011, the trend is not clear and the iron concentrations are stable between 35 and $40 \mathrm{mg} / \mathrm{L}$.

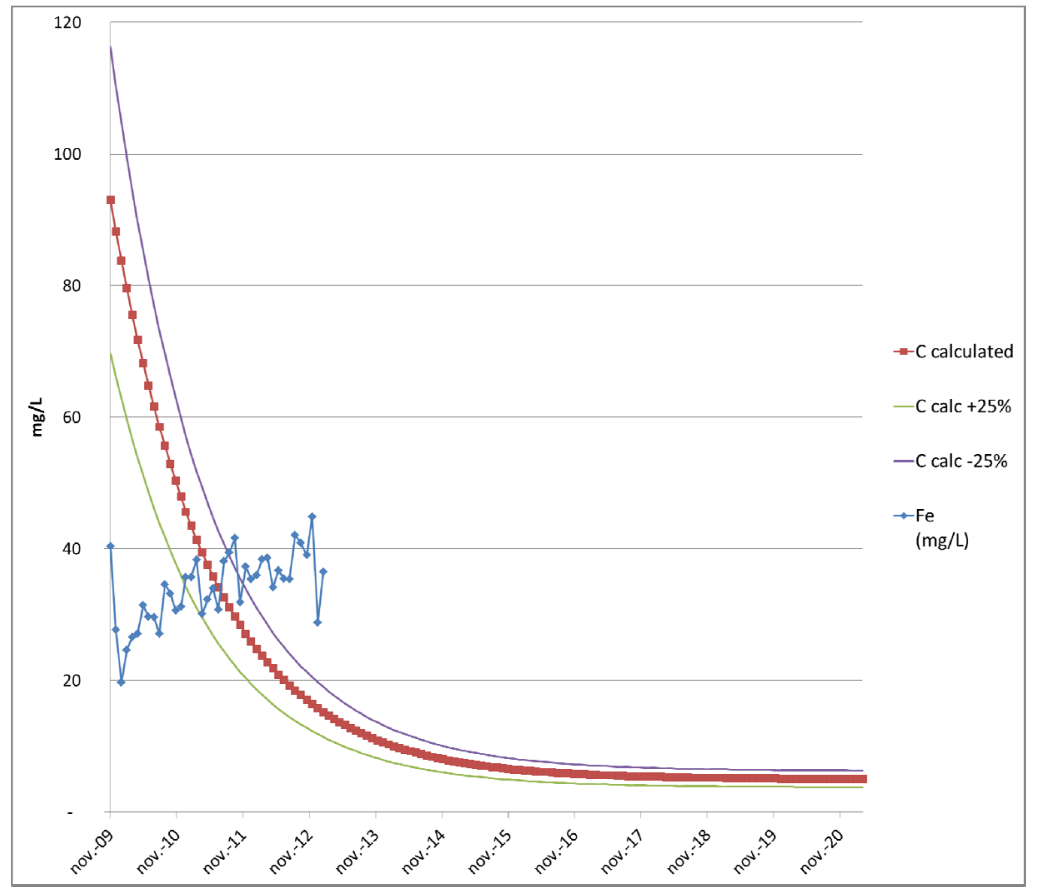

Figure 6 Mine water iron concentrations, comparison with expected values (mg/L) 
The concentration decrease models indicate that immediately after the end of filling the concentration gradient should be the steepest. A decreasing trend should be seen over the 2009-2010-2012 period, all the more so since the western reservoir is well delimited and meets the limit conditions of the Younger model:

- the mine is completely flooded and there is no change in groundwater level favourable to oxidation;

- the mine is under very thick overburden and is far from any outcropping of the coal that could be source areas of iron oxides.

\subsection{Possible explanations and calibration of a new model}

The predictive model used is in the form of calculation of the residual concentration $(\mathrm{Cr})$, calculated by iteration as a function of residual concentration at time $\mathrm{t}-1$. The equation is written:

$C_{r(n)}=\frac{V \cdot C_{r(n-1)}+q \cdot\left(t_{(n)}-t_{(n-1)}\right) \cdot C_{s t a b}}{\left.V+q \cdot\left(t_{(n)}\right)^{-t(n-1)}\right)}$

(equation 1)

Where:

- $\operatorname{Cr}(n)$ : is the residual concentration at time $t(n)$. The concentration at time 0 is equal to the peak concentration: $\operatorname{Cr}(0)=$ Cpeak.

- $\quad \mathrm{V}$ : the volume of the reservoir mobilised during renewal by influxes of water. In the model proposed originally, 10 per cent of the total reservoir volume was used for calculation (Vtot = $18 \mathrm{Mm}^{3}$ ).

- Cstab: final reservoir concentration.

- $\mathrm{q}$ : water inflow rate, at the origin of dilution in the reservoir.

The time step used in the calculation is equal to 1 month: $(t(n)-t(n-1)=1$ month).

To take account of concentrations measured over three years while remaining in line with Younger's model we can assume a very slow dilution rate. The parameters allowing partial fit between observations and the model are as follows:

- $\quad$ peak $=40 \mathrm{mg} / \mathrm{L}$.

- $C s t a b=5 \mathrm{mg} / \mathrm{L}$ (the value taken in the initial model is retained).

- $Q=65 \mathrm{~m}^{3} / \mathrm{h}$ (average flow rate from start of pumping).

- Percentage of total reservoir volume mobilised: 80 per cent (value which greatly reduces the rate of decrease and allows for the measurements of the past two years).

In this case, the rising trend observed over the first two years would be considered as a transient phase of mobilisation of the mine reservoir $\left(850,000 \mathrm{~m}^{3}\right.$ pumped between November 2009 and July 2011, i.e. 5 per cent of total reservoir volume).

Table 3 gives details of the characteristic parameters used in the original model and new parameters allowing partially for observations (Figure 7). 
Table 3 Characteristic values used in the Younger model

\begin{tabular}{ccc}
\hline Parameter & $\begin{array}{c}\text { Cesame model } \\
\text { (Blachere, 2003) }\end{array}$ & Hypothesis \\
\hline $\operatorname{Cr}(0)=$ C peak (mg/L) & 98 & 40 \\
Cstab (mg/L) & 5 & 5 \\
q (m3/h) & 140 & 65 \\
$\begin{array}{c}\text { V, a percentage of } \\
\text { Vtot }=18 \mathrm{Mm}^{3}\end{array}$ & $10 \%$ & $80 \%$ \\
\hline
\end{tabular}
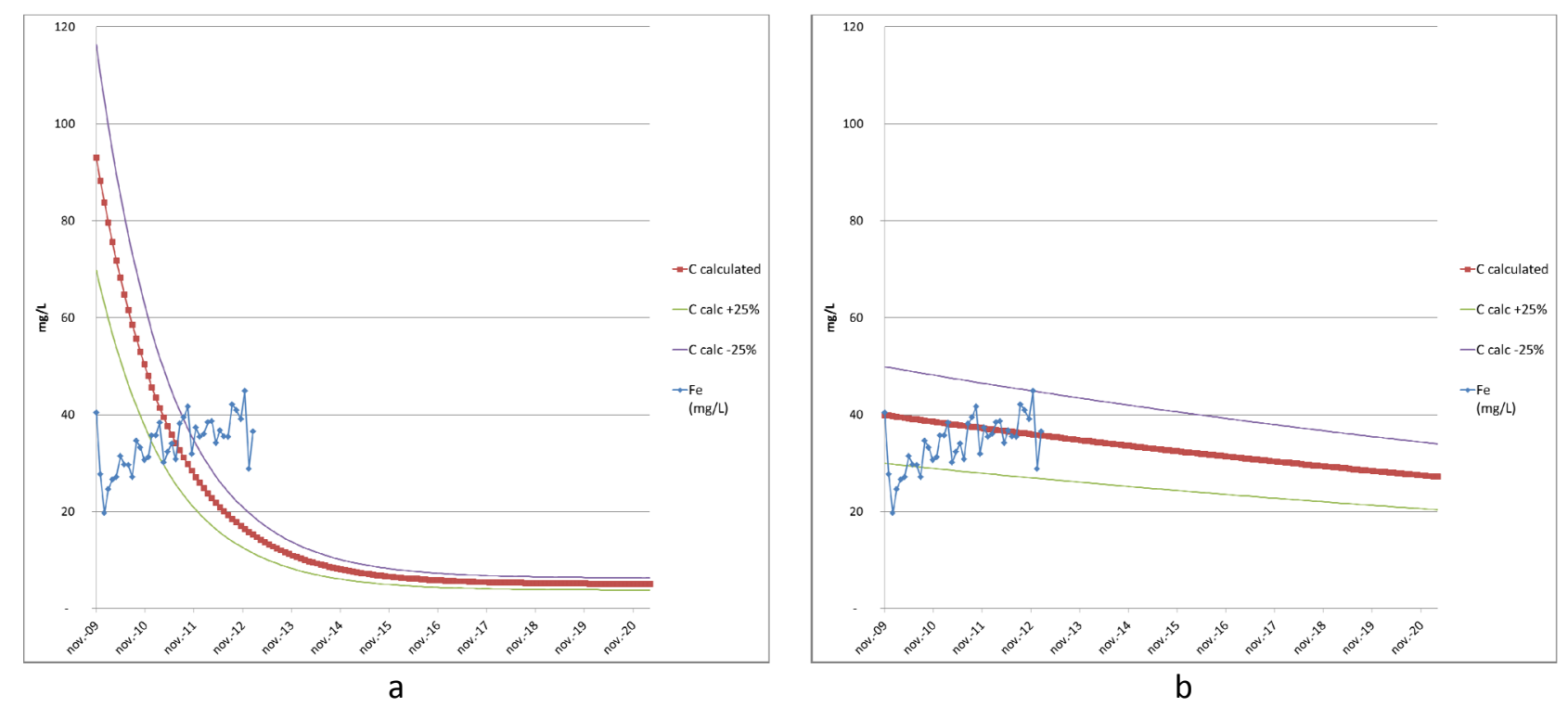

Figure 7 Simulations to take account of observations. Original model (a), hypothesis (b)

Despite the preceding hypotheses, a strictly decrease model does not provide a truly convincing explanation of the observations. Further experience will make it possible to develop future scenarios. Feedback analysis as conducted for iron will be carried out for other substances such as manganese and sulphates.

The direct consequence for the treatment plant manager is that the volumes of sludge generated will be greater than initially foreseen. Although exceptional, more frequent regular pond cleaning operations will have to be planned.

\subsection{Efficiency of the La Houve plant}

The limit on iron concentration to be complied with for discharge into the natural environment is set, by Prefectoral Order, at $2 \mathrm{mg} / \mathrm{L}$. Such a high value has never been reached since commissioning in November 2009 (Figure 8) and the plants removal efficiency is on average 98 per cent, and is always above 94 per cent (Figure 9).

A seasonal pattern can be observed with a slight drop in efficiency in the winter (Figure 9). This is attributed to lower biological activity in the reed lagoons. The iron concentrations at discharge are generally below 
$0.5 \mathrm{mg} / \mathrm{L}$ and reach values close to $1 \mathrm{mg} / \mathrm{L}$ during the months when the vegetation is dormant (Kaiser, 2013).

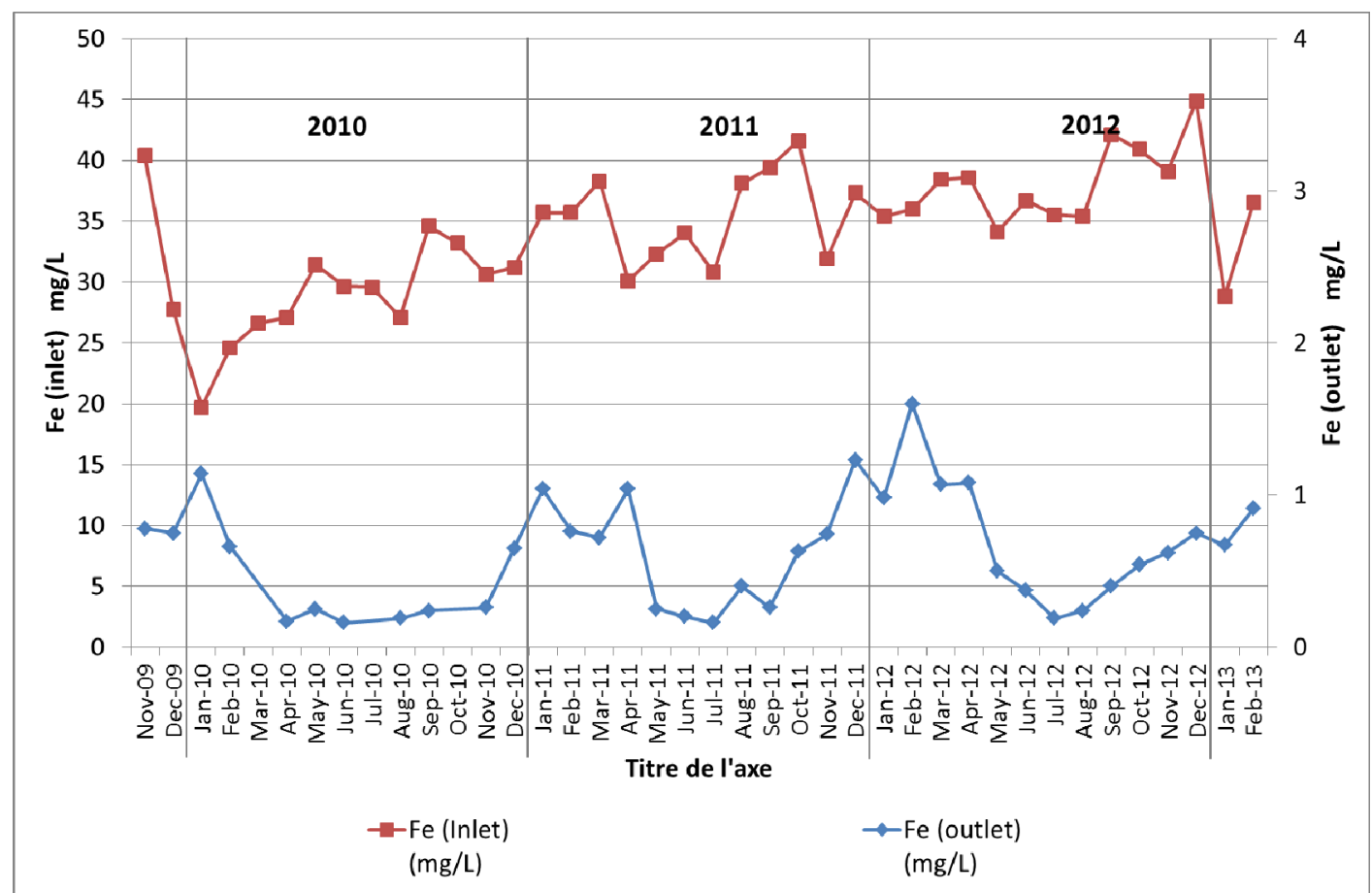

Figure 8 Iron concentrations at inlet (left scale) and at outlet (right scale) to the La Houve treatment plant (from November 2009 to February 2013)

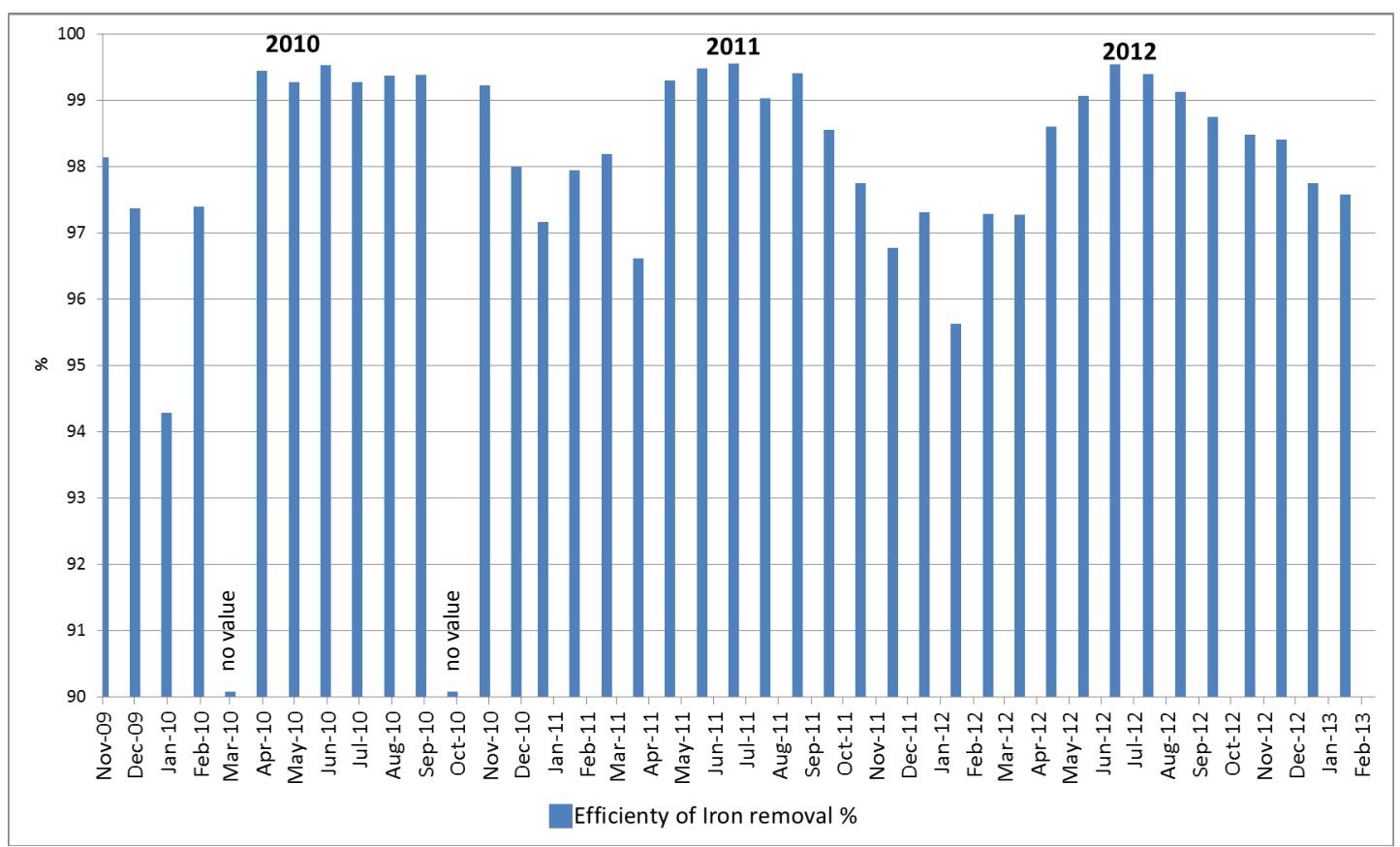

Figure 9 Efficiency of La Houve plant as percentage of iron removed (November 2009 to February 2013 


\section{$4 \quad$ Conclusions}

The level of iron mineralisation of the mine waters in the Lorraine coal field is such that the water cannot be discharged directly into the natural environment and requires treatment. The solution adopted comprises three pumping stations and passive water treatment by aeration, settling and lagooning.

Studies to predict the decrease in the iron content of the water were conducted by the former mine operator, based on the Younger model developed at Newcastle University (UK) on the basis of observations from over 80 mines in Great Britain. The model had been compared with other mine reservoirs in France and adapted by the consulting firm Cesame. The kinetics of decrease fitted well with observations for small mine reservoirs with short filling times. For larger reservoirs, the decrease times observed were shorter than those predicted and this phenomenon was interpreted as a partial mobilisation of the mine reservoir volume (10 to 15 per cent); this was assumed in the case of the La Houve reservoir.

The La Houve pumping and treatment unit has been in operation since 2009 and feedback on the western mine reservoir shows a notable difference between the iron concentrations expected and those observed over three years. Decrease in iron concentration, which should have been effective very rapidly, is not observed and there appears even to be a slightly rising trend. This development, contrary to forecasts, could be explained by the mobilisation of a much greater volume of the mine reservoir (around 80 per cent).

For the BRGM, the manager of the treatment plant, maintained iron concentrations imply greater production of sludge than planned. Additional pond cleaning operations are therefore to be included in the planning of operations. The uncertainties relating to the quantities of iron to be treated support the former operator's choice of a passive treatment plant.

The phenomenon nonetheless remains complex and further experience will allow scenarios for future development to be more closely defined. The analysis of feedback conducted for iron will be extended to other substances such as manganese and sulphates.

\section{References}

Blachere A., Lefort D., (2003) Etude prévisionnelle de la qualité des eaux après remplissage des mines des secteurs Est, Ouest et Centre. Bureau d'études Cesame.

Blachere A., Lefort D., (2003) ${ }^{b}$ Prévision de la qualité des eaux de la mine de La Houve.

Kaiser J., avec la collaboration de Vicentin S. (2013) - Bassin houiller lorrain. Gestion de la station de pompage et station de traitement des eaux de résurgence minière - Commune de Creutzwald (57150), secteur Ouest. Rapport annuel 2012. BRGM/RP-61812-FR, 74 p., 10 fig., 15 tabl., 21 ann. (3 ann. en volume séparé)

ANTEA, (2004). Secteur Ouest, U.E. La Houve (57). Etats transitoire et final des eaux souterraines et superficielles après arrêt des exhaures. Etude hydrogéologique et hydrologique. Rapport A 33301/A.

PIRAMID Consortium (2003). Engineering guidelines for the passive remediation of acidic and/or metalliferous mine drainage and similar wastewaters. European Commission 5th Framework RTD Project no. EVK1-CT-1999-000021 "Passive in-situ remediation of acidic mine / industrial drainage" (PIRAMID). University of Newcastle Upon Tyne, Newcastle Upon Tyne UK. $166 \mathrm{pp}$. 